\title{
Improvement in Linearity of Calibration Curves Using of Palladium Modifier in Electrothermal Vaporization/ICP-MS and Determination of Ultratrace Metallic Impurities on Silicon Wafers
}

\author{
Hiroshi MITSUMATA and Toshio MORI \\ Lighting Company, Matsushita Electric Industrial Co., Ltd., 1-1, Saiwai-cho, Takatsuki-shi 569-1193
}

\begin{abstract}
加熱気化/ICP-MS におけるパラジウムモディファイヤーの使用による検量線の直線性改善と シリコンウェハ表面超微量金属の定量

光亦博志·森 俊雄

松下電器産業(株) 照明社, 569-1193 大阪府高梘市幸町 1-1
\end{abstract}

\begin{abstract}
An electrothermal vaporization (ETV)/inductively coupled plasma mass spectrometry (ICP-MS) technique has been developed to determine the ultratrace metallic impurities of 10 elements $(\mathrm{Na}, \mathrm{Mg}, \mathrm{Al}, \mathrm{Cr}, \mathrm{Mn}, \mathrm{Fe}, \mathrm{Ni}, \mathrm{Cu}$, $\mathrm{Zn}$, and $\mathrm{Pb}$ ) in the natural oxide layer on a $\mathrm{Si}$ wafer. $\mathrm{SiO}_{2}$ reacts to form $\mathrm{SiF}_{6}{ }^{2-}$ with hydrofluoric acid in vapor-phase decomposition. The pyrolysis temperature $\left(150^{\circ} \mathrm{C}\right)$ for eliminating $\mathrm{SiF}_{6}{ }^{2-}$ was added to the ETV operating conditions, because the existence of ${ }^{28} \mathrm{Si}^{28} \mathrm{Si}_{2}$, and ${ }^{28} \mathrm{SiO}_{2}$ due to $\mathrm{SiF}_{6}{ }^{2-}$ influences the ion intensities of ${ }^{27} \mathrm{Al},{ }^{56} \mathrm{Fe}$, and ${ }^{60} \mathrm{Ni}$, respectively. Furthermore, adding $25 \mathrm{ng}$ of a palladium modifier improved the linearity of each calibration curve. As a result, it was possible to determine the 10 elements in concentration ranges of 20 (40) $-10000 \mathrm{pg} \mathrm{ml}^{-1}$. The recovery percentages obtained by adding the mixed standard solution to the sample solution were $95-105 \%$, showing that the ETV/ICP-MS measurements are accurate. The detection limit $(3 \sigma)$ was approximately $10^{6}(\mathrm{~Pb})-10^{8}(\mathrm{Na})$ atoms $\mathrm{cm}^{-2}$ for a Si wafer with a diameter of $130 \mathrm{~mm}$. This method can be applied to the above wafer to determine the 10 metallic elements $\left(10^{9}-10^{11}\right.$ atoms $\left.\mathrm{cm}^{-2}\right)$.
\end{abstract}

[Received October 2, 2005; Accepted December 20, 2005]

Key-words: Silicon wafer, Metallic impurities, Hydrofluoric acid vapor decomposition, ETV/ICP-MS, Pd modifier

1. Introduction

Inductively coupled plasma mass spectrometry (ICPMS), 1)-3) furnace atomic absorption spectrometry (FAAS $)^{4)-6)}$ and total-reflection X-ray fluorescence analysis $(\text { TRXF })^{\left.7)^{-9}\right)}$ have often been used to evaluate metallic contamination on silicon $(\mathrm{Si})$ wafers. FAAS is available to measure the $\mathrm{n} \mathrm{ml}^{-1}$ level impurities in microsamples containing volatile components, but is time consuming in multielemental analysis because of singleelemental measurement. TRXF can measure contamination distribution without damaging the Si wafer. However, TRXF has problems with standard sample preparation. Among these methods, ICP-MS using electrothermal vaporization (ETV) is the most sensitive, and it is available for multielemental measurements of the microsample solution mentioned above. Furthermore, ETV/ ICP-MS avoids spectral influence due to solvents, such as the spectral influence of ${ }^{40} \mathrm{Ar}^{16} \mathrm{O}$ on the ${ }^{56} \mathrm{Fe}$ ion intensity, which occurs in the nebulizer method. There are a few reports on the analysis of Si wafers using ETV/ICP-MS. ${ }^{\left.1{ }^{1}-12\right)}$ Ruth et al. reported that the quantitation limits of 10 elements (e.g., Fe, $\mathrm{In}, \mathrm{B}, \mathrm{Cr}, \mathrm{Mn}, \mathrm{Ni}$ and $\mathrm{Cu}$ ) are approximately $10^{8}-10^{10}$ atoms $\mathrm{cm}^{-2} .{ }^{10)}$ Takenaka et al. developed the method for the microdepth profiling of $\mathrm{Cr}, \mathrm{Fe}, \mathrm{Ni}$ and $\mathrm{Cu}$ in $\mathrm{Si}$ wafers. ${ }^{11)} \mathrm{Hub}$ et al. reported that the detection limits of 8 elements (e.g., Fe, $\mathrm{Al}, \mathrm{Mg}$, and $\mathrm{Na}$ ) are approximately $10^{8}-10^{9}$ atoms $\mathrm{cm}^{-2} .^{12}$ However, a more sensitive method is required to suit more highly integrated and refined semiconductor devices. Therefore, to apply ETV/ICP-MS analysis to 10 elements ( $\mathrm{Na}, \mathrm{Mg}$, $\mathrm{Al}, \mathrm{Cr}, \mathrm{Mn}, \mathrm{Fe}, \mathrm{Ni}, \mathrm{Cu}, \mathrm{Zn}$, and $\mathrm{Pb}$ ) in the natural oxide $\left(\mathrm{SiO}_{2}\right)$ layer on the $\mathrm{Si}$ wafer, we chiefly examined the electrothermal condition and improvements in the linearity of the calibration curves, as discussed below.

$\mathrm{SiO}_{2}$ reacts to form $\mathrm{SiF}_{6}{ }^{2-}$ with hydrofluoric acid $(\mathrm{HF})$ in vapor-phase decomposition (VPD) ${ }^{13}$ ) and liquid-phase decomposition (LPD), ${ }^{14)}$ and the existence of ${ }^{28} \mathrm{Si}^{28} \mathrm{Si}_{2}$, and ${ }^{28} \mathrm{Si}^{16} \mathrm{O}_{2}$ due to $\mathrm{SiF}_{6}{ }^{2-}$ influences the ion intensities of ${ }^{27} \mathrm{Al},{ }^{56} \mathrm{Fe}$ and ${ }^{60} \mathrm{Ni}$, respectively. To avoid such interference it has been reported that using a sulfuric acid treatment, $\mathrm{SiF}_{6}{ }^{2-}$ can be eliminated from each $\mathrm{Si}$-etched sample solution used to measure the metal depth profile of the Si wafer. ${ }^{11)}$ The handling of this treatment is fairly complicated, therefore, we added the optimum pyrolysis to the ETV conditions for eliminating $\mathrm{SiF}_{6}{ }^{2-}$ without adding sulfuric acid.

We discuss the linearity of the calibration curves and the effect of the modifier on improving linearity in low-concentration ranges. ${ }^{15), 16)} \mathrm{We}$ assumed that transport loss for each analyte element occurred between the chamber and the ICP torch, ${ }^{17), 18)}$ because we found that significant ion intensity losses are observed in the 10 calibration curves obtained only from the mixed standard solution; we then examined which modifier acted more effectively on transport loss. As a result, using more than $25 \mathrm{ng}$ of the Palladium (Pd) modifier, we obtained a good linearity for the 10 calibration curves in the concentration range of $\left(20(40)-10000 \mathrm{pg} \mathrm{ml}^{-1}\right)$. The detection limits $(3 \sigma)$ were $1 \mathrm{pg} \mathrm{ml}^{-1}(\mathrm{~Pb})-20 \mathrm{pg} \mathrm{ml}^{-1}(\mathrm{Cr})$ and 2 $\times 10^{5}$ atoms cm ${ }^{-2}(\mathrm{~Pb})-6 \times 10^{7}$ atoms $\mathrm{cm}^{-2}(\mathrm{Na})$ for a $\mathrm{Si}$ wafer with a diameter of $130 \mathrm{~mm}$. The proposed method was applied to determine the 10 metallic elements $\left(10^{9}-10^{11}\right.$ atoms $\mathrm{cm}^{-2}$ ) in the natural oxide layer on a Si wafer with a diameter of $130 \mathrm{~mm}$. 


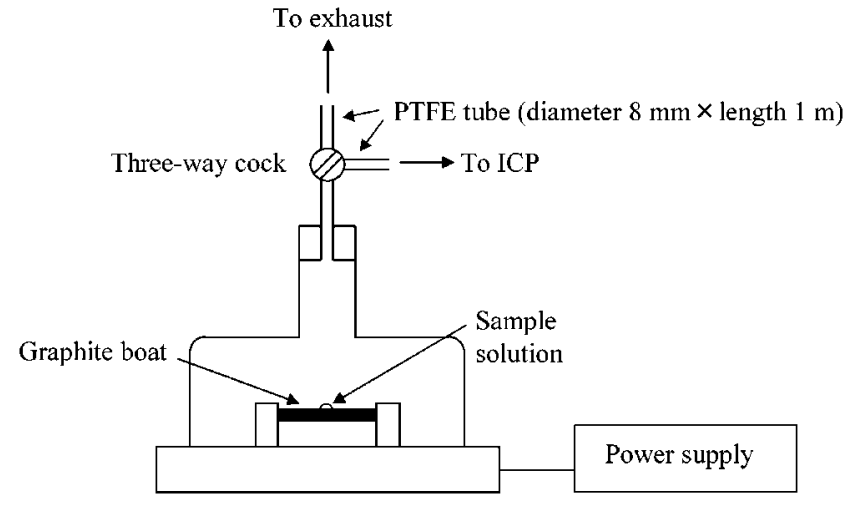

Fig. 1. Schematic diagram of ETV chamber.

\section{Experimental}

2.1 Instruments and apparatus

We used a PMS 2000 ICP mass spectrometer (Yokagawa Analytical Systems, Tokyo) for the multielemental analysis. We used EV 2000 (Yokogawa Analytical Systems) as a furnace for the ETV. An electrothermal vaporizer was connected to an ICP torch using a PTFE tube $1 \mathrm{~m}$ in length and $8 \mathrm{~mm}$ in diameter. Figure 1 shows a schematic diagram of the ETV chamber. After the sample solutions were injected into the graphite boat using an autosampler (ES 2000 (Yokogawa)), the samples underwent 4 different stages: drying, pyrolysis, vaporization and cleanup. Vapor containing the 10 elements that originated during vaporization was introduced through the tube to the ICP. However, vapors that originated during drying, pyrolysis, and cleanup were exhausted. All wafers were exposed to $\mathrm{HF}$ vapor in a closed container to decompose the natural $\mathrm{SiO}_{2}$ layer. ${ }^{19}$ )

\subsection{Reagents}

A standard solution was prepared by diluting the standard 31-element metal stock solution XSTC-13 $\left(10 \mu \mathrm{g} \mathrm{ml}^{-1}\right.$ of each element) that contains the above 10 elements (SPEX CertiPrep Inc., Metuchen, N. J., USA) with $1 \% \mathrm{HNO}_{3}$. We used $\mathrm{HNO}_{3}(68 \%)$ and $\mathrm{HF}(38 \%)$ of high-purity solutions (TAMAPURE AA-100, Tama Chemicals, Kanagawa). For the modifier, we used $1000 \mu \mathrm{g} \mathrm{ml}^{-1}$ of each SPEX metal standard solution (the $\mathrm{Rh}, \mathrm{Ir}, \mathrm{Pd}$, and Pt chloride forms of each element). We also used deionized water obtained from a Millipore QSP water purification system (Nihon Milliporekogyo, Tokyo).

\subsection{Procedure}

Wafer samples were placed in a closed container filled with $\mathrm{HF}$ vapor overnight. Each surface on the Si wafer was then scanned with $1 \% \mathrm{HNO}_{3}$. Next, $25 \mu \mathrm{l}$ of the $1 \mu \mathrm{g} \mathrm{ml}^{-1} \mathrm{Pd}$ solution was added to the collected droplets, and the solution was diluted to $1 \mathrm{ml}$ to prepare the sample solution with $1 \% \mathrm{HNO}_{3}$. Each $25 \mu \mathrm{l}$ sample was injected into the graphite boat followed by sequential multielemental measurement of the ion intensities of five elements in each group (group 1: $\mathrm{Na}, \mathrm{Mg}, \mathrm{Al}, \mathrm{Cr}$, and $\mathrm{Mn}$; group 2: $\mathrm{Fe}, \mathrm{Ni}, \mathrm{Cu}, \mathrm{Zn}$, and $\mathrm{Pb}$ ) using the $\mathrm{ETV} /$ ICP-MS operating conditions shown in Tables 1 and 2. The preparation of the sample solution was carried out in a class100 clean bench. The ETV/ICP-MS measurements were carried out in a class-1000 clean room.

\section{Results and discussion}

\subsection{ETV/ICP-MS operating conditions}

We examined high-frequency power, carrier gas flow rate
Table 1. ICP-MS Operating Conditions

\begin{tabular}{|c|c|}
\hline \multicolumn{2}{|c|}{ ICP-MS spectrometer (YOKOGAWA PMS 2000) } \\
\hline RF power $/ \mathrm{kW}$ & 1.0 \\
\hline $\begin{array}{l}\text { Sampling depth / mm } \\
\text { (from load coil) }\end{array}$ & 10 \\
\hline Outer Ar flow rate $/ 1 \mathrm{~min}^{-1}$ & 15 \\
\hline Auxiliary Ar flow rate $/ 1 \mathrm{~min}^{-1}$ & 0.5 \\
\hline Carrier Ar flow rate $/ 1 \mathrm{~min}^{-1}$ & 0.9 \\
\hline \multicolumn{2}{|l|}{ Data acquisition } \\
\hline \multirow[t]{2}{*}{ Analyte element } & ${ }^{23} \mathrm{Na},{ }^{24} \mathrm{Mg},{ }^{27} \mathrm{Al},{ }^{57} \mathrm{Cr},{ }^{55} \mathrm{Mn}$, \\
\hline & ${ }^{56} \mathrm{Fe},{ }^{60} \mathrm{Ni},{ }^{63} \mathrm{Cu},{ }^{66} \mathrm{Zn},{ }^{208} \mathrm{~Pb}$ \\
\hline Dwell time / ms & 19 \\
\hline Scan mode & Peak hopping \\
\hline Points/spectral peak & 1 \\
\hline Signal measurement & Peak area \\
\hline $\mathrm{m} / \mathrm{z}$-monitored / measurement & ycle \\
\hline
\end{tabular}

Table 2. ETV Operating Conditions for Wafer Sample Solutions

\begin{tabular}{lccc}
\hline Stage & Temperature $/{ }^{\circ} \mathrm{C}$ & Ramp $/ \mathrm{s}$ & Hold $/ \mathrm{s}$ \\
\hline Drying & $0-90$ & 10 & 0 \\
Pyrolysis & 150 & 30 & 60 \\
Vaporization & 2400 & 0 & 3 \\
Cleanup & 2800 & 0 & 3
\end{tabular}

Carrier Ar flow rate $0.91 \mathrm{~min}^{-1}$, Sample injection volume $25 \mu \mathrm{l}$.

Table 3. ETV Fundamental Operating Conditions

\begin{tabular}{lccc}
\hline Stage & Temperature $/{ }^{\circ} \mathrm{C}$ & Ramp $/ \mathrm{s}$ & Hold $/ \mathrm{s}$ \\
\hline Drying & $0-90$ & 10 & 0 \\
Vaporization & 2400 & 0 & 3 \\
Cleanup & 2800 & 0 & 3
\end{tabular}

Carrier Ar flow rate $0.91 \mathrm{~min}^{-1}$, Sample injection volume $25 \mu 1$.

and sampling depth, which influenced the ion intensities of the 10 elements. The ICP-MS operating conditions were optimized for the multielemental analysis. Table 1 shows the optimum ICP-MS operating conditions. Next, we examined the ETV conditions, pyrolysis temperature, and vaporization temperature, which influenced the ion intensities of the 10 elements. Twenty-five micromilliliters of the mixed standard solution were injected into the graphite boat, and the ion intensities of the 10 elements were then measured using the five elements mentioned above. We optimized the ETV fundamental operating conditions for the multielemental analysis. Table 3 shows the ETV fundamental operating conditions. 3.2 Effect of modifier on ion intensities of 10 elements Using the mixed standard solutions, each calibration curve was obtained at concentrations ranging from 0.2 to $10 \mathrm{ng}$ $\mathrm{ml}^{-1}$. As the example in Fig. 2 shows, in the calibration curve obtained for copper, a significant ion intensity loss was 


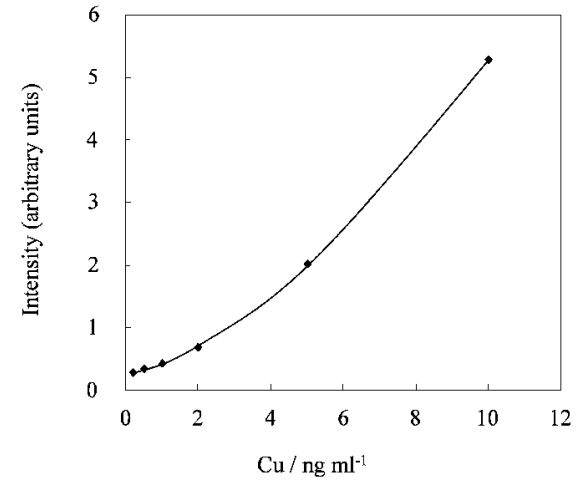

Fig. 2. Copper calibration curve without using modifier.

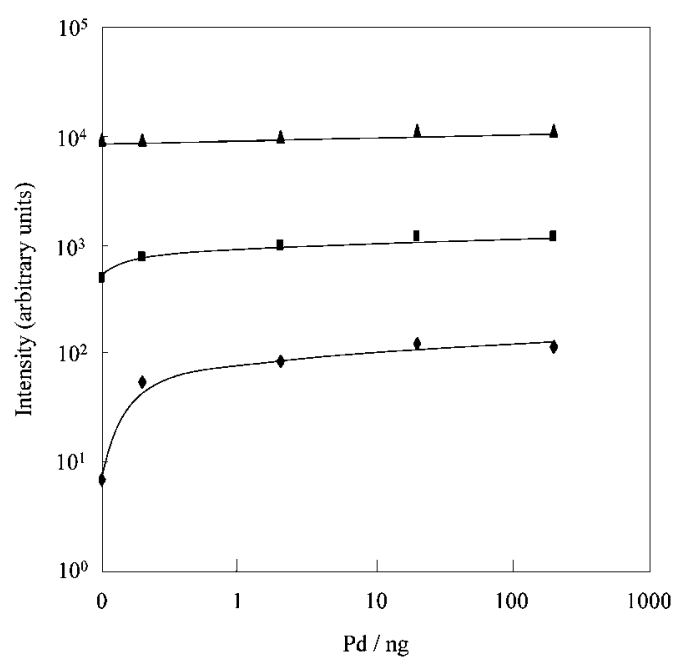

Fig. 3. Effect of palladium on copper ion intensity. $\mathrm{Cu}$ : $10 \mathrm{pg},>1 \mathrm{pg}$.

observed in the lower concentration range. The linearity of the other nine calibration curves was similar to that of copper, although these results are not shown here. We guessed that the analyte adsorption on the inner wall of the transport line between the chamber and the ICP torch caused a decrease in ion intensity. ${ }^{17), 18)}$ To improve the transport loss of the 10 elements it was necessary to use a modifier. ${ }^{15), 16)}$ We examined $\mathrm{Rh}, \mathrm{Ir}, \mathrm{Pd}$ and $\mathrm{Pt}$ of the highest available purity to determine which modifier acts more effectively. We found that the impurities contained in the $\mathrm{Pd}$ modifier were the smallest among the four modifiers, although the effects obtained using the four modifiers were similar, and the ion intensities of the 10 elements were not influenced by spectral interference from the Pd modifier. The amount of Pd modifier used was stepwisely varied at concentrations ranging from 0 to $100 \mathrm{ng}$, and was followed by measuring the ion intensities of the ten elements. As an example, Fig. 3 shows that when more than 25 ng of $\mathrm{Pd}$ was used, we obtained a constant $\mathrm{Cu}$ ion intensity. The smaller the decrease in $\mathrm{Cu}$ amount, the larger the increase in $\mathrm{Cu}$ ion intensity. The results for the other nine elements were similar to the $\mathrm{Cu}$ results, although these results are not shown here.

3.3 ETV operating conditions for eliminating fluorosilicate matrix

Fujiwara et al. reported that the concentration of silicon in the practical sample solution obtained from the Si wafer with

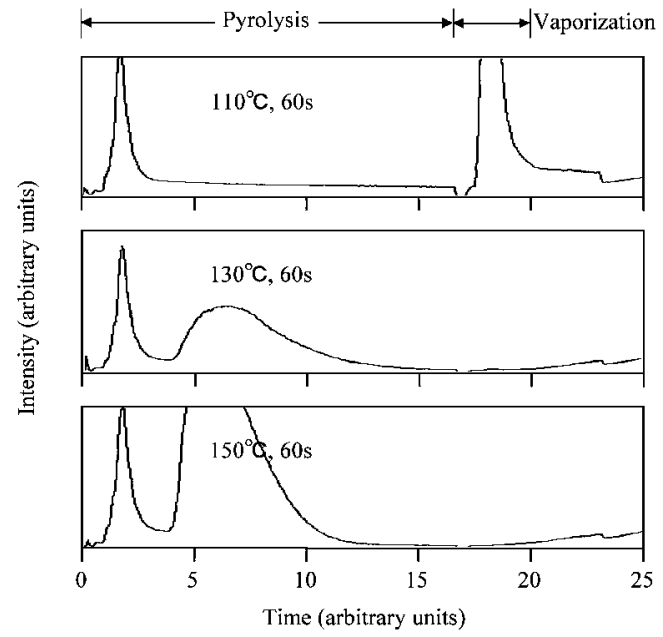

Fig. 4. Effect of pyrolysis temperature on silicon ion intensities. ${ }^{28} \mathrm{Si}$ ion intensities were monitored in successive steps from pyrolysis to vaporization.

a diameter of $150 \mathrm{~mm}$ was $40-4000 \mu \mathrm{g} \mathrm{ml}^{-1}$ (oxide layer thickness: $1-100 \mathrm{~nm}) .{ }^{3)}$ The ion intensities of ${ }^{27} \mathrm{Al},{ }^{56} \mathrm{Fe}$, and ${ }^{60} \mathrm{Ni}$, are, respectively, influenced by spectral interference due to ${ }^{28} \mathrm{Si}^{28} \mathrm{Si}_{2}$, and ${ }^{28} \mathrm{Si}^{16} \mathrm{O}_{2}$ from $\mathrm{SiF}_{6}{ }^{2-}$. Therefore, we examined the ETV conditions for eliminating $\mathrm{SiF}_{6}{ }^{2-}$ using the ETV/ ICP-MS operating conditions shown in Tables 1 and 3 , and added the pyrolysis stage. The pyrolysis temperatures and the vaporization temperature were set at 110,130 and $150^{\circ} \mathrm{C}$, and $2400^{\circ} \mathrm{C}$, respectively, and the degree of remaining $\mathrm{SiF}_{6}{ }^{2-}$ was examined, monitoring the ${ }^{28} \mathrm{Si}$ ion intensity in successive steps from pyrolysis to vaporization. As shown in Fig. 4, the ${ }^{28} \mathrm{Si}$ signal was not detected when the pyrolysis temperature was elevated to $150^{\circ} \mathrm{C}$. As a result, it was possible to separate the 10 elements from $\mathrm{SiF}_{6}{ }^{2-}$ using the pyrolysis stage $\left(150^{\circ} \mathrm{C}\right.$, $60 \mathrm{~s})$. As shown in Table 2, this pyrolysis temperature was added to the ETV/ICP-MS operating conditions shown in Table 3.

3.4 Calibration, recovery and detection limits

The recovery and detection limits were examined using mixed standard solutions under the optimum ETV/ICP-MS conditions mentioned above. As shown in Figs. 5(a) and (b), 10 linear calibration curves were obtained ranging from 20 to $10000 \mathrm{pg} \mathrm{ml}^{-1}$ (Fe, $\mathrm{Mg}, \mathrm{Pb}, \mathrm{Na}, \mathrm{Mn}, \mathrm{Al}$, and $\mathrm{Zn}$ ), and from 40 to $10000 \mathrm{pg} \mathrm{ml}^{-1}(\mathrm{Cu}, \mathrm{Cr}$, and $\mathrm{Ni})$. Next, to examine the recovery percentages of the 10 elements, mixed standard solutions containing $200 \mathrm{pg}$ of each element were added to the practical sample solution (1) in the application mentioned below. The recovery percentages showed good values of 95-105\% in ultra-microanalysis, although different values were obtained for each element. As shown in Table 4, the detection limits $(3 \sigma)$ for a Si wafer with a diameter of $130 \mathrm{~mm}$ were $6 \times 10^{5}(\mathrm{~Pb})-6 \times 10^{7}(\mathrm{Na})$ atoms $\mathrm{cm}^{-2}$, and $2 \times 10^{5}$ $(\mathrm{Pb})-2 \times 10^{7}(\mathrm{Na}, \mathrm{Al}$ and $\mathrm{Cr})$ atoms $\mathrm{cm}^{-2}$ for a Si wafer with a diameter of $200 \mathrm{~mm}$. To compare the detection limits shown in Table 4 with those of other reports, we chose an Fe analyte element as representative of the 10 analyte elements, because Fe impurity is one of the most important contaminants in the semiconductor manufacturing process. The Fe detection limit (pg) shown in Table 4 was in good agreement with the $0.3 \mathrm{pg}$ of Tsukahara et al., ${ }^{20)}$ and was two orders of magnitude lower than those of FAAS.4),5) 

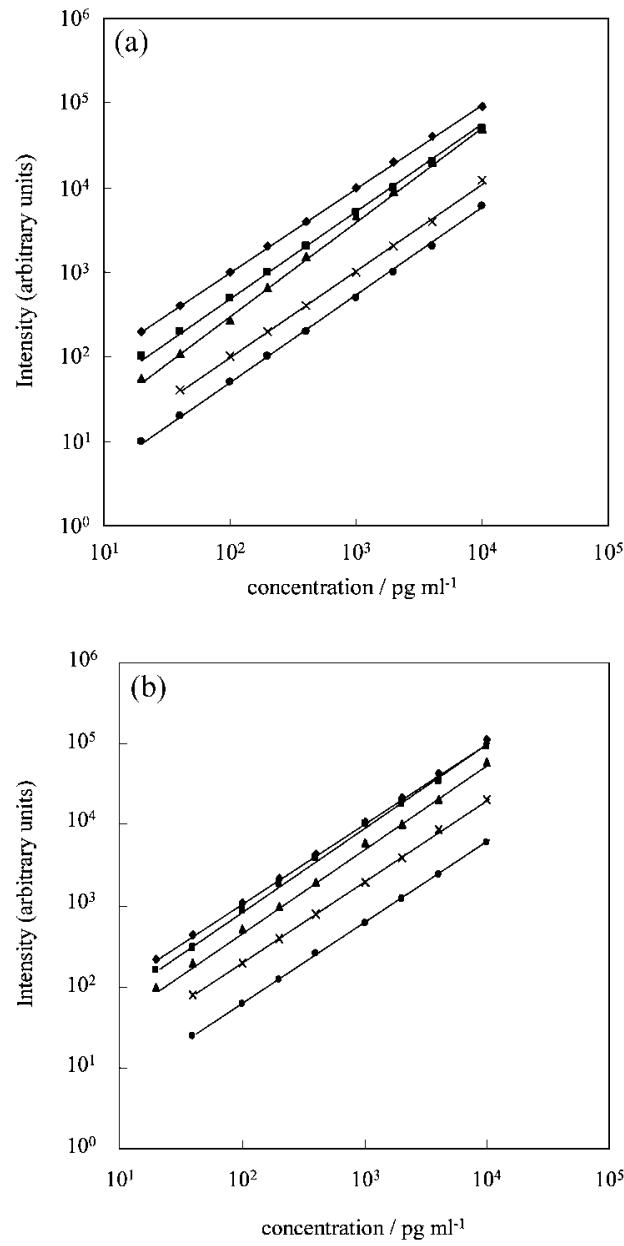

Fig. 5. (a) Calibration curves for iron, magnesium, lead, nickel, and zinc. Fe, $\mathrm{Mg}, \boldsymbol{\Delta} \mathrm{Pb}, \times \mathrm{Ni}, \mathrm{Zn}$. (b). Calibration curves for sodium, manganese, aluminum, copper, and chromium. $\wedge \mathrm{Na}$, $\mathrm{Mn}, \Delta \mathrm{Al}, \times \mathrm{Cu}, \mathrm{Cr}$

Table 4. Detection Limits for ETV/ICP-MS

\begin{tabular}{|c|c|c|c|c|c|}
\hline \multirow{2}{*}{ Analyte element } & \multicolumn{2}{|c|}{ In the solution } & \multicolumn{3}{|c|}{ In the wafer sample $/ \times 10^{7}$ atoms $\mathrm{cm}^{-2}$} \\
\hline & $\mathrm{pg} \mathrm{m \textrm {l } ^ { - 1 }}$ & pg & (A) & (B) & (C) \\
\hline $\mathrm{Na}$ & 10 & 0.3 & 6 & 4 & 2 \\
\hline $\mathrm{Mg}$ & 3 & 0.08 & 2 & 1 & 0.6 \\
\hline $\mathrm{Al}$ & 10 & 0.3 & 5 & 3 & 2 \\
\hline $\mathrm{Cr}$ & 20 & 0.4 & 5 & 3 & 2 \\
\hline $\mathrm{Mn}$ & 2 & 0.04 & 0.5 & 0.3 & 0.2 \\
\hline $\mathrm{Fe}$ & 10 & 0.3 & 2 & 2 & 0.8 \\
\hline $\mathrm{Ni}$ & 8 & 0.2 & 2 & 1 & 0.6 \\
\hline $\mathrm{Cu}$ & 10 & 0.3 & 2 & 1 & 0.7 \\
\hline $\mathrm{Zn}$ & 10 & 0.4 & 2 & 1 & 0.7 \\
\hline $\mathrm{Pb}$ & 1 & 0.02 & 0.06 & 0.04 & 0.02 \\
\hline
\end{tabular}

Wafers diameter: (A) $130 \mathrm{~mm}$, (B) $150 \mathrm{~mm}$, (C) $200 \mathrm{~mm}$.

\subsection{Application}

The proposed method was applied to determine 10 metallic elements on three purchased $\mathrm{Si}$ wafer samples. The samples were also analyzed using FAAS and Table 5 shows the analytical results. The results obtained by ETV/ICP-MS were in good agreement with those of FAAS. The analytical values of $\mathrm{Na}$ and $\mathrm{Al}$ were the highest among the 10 elements and these
Table 5. Analytical Results of Silicon Wafers

\begin{tabular}{|c|c|c|c|c|c|c|}
\hline \multirow{2}{*}{$\begin{array}{l}\text { Analyte element / } \\
\times 10^{9} \text { atoms } \mathrm{cm}^{-2}\end{array}$} & \multicolumn{2}{|c|}{ Sample (1) } & \multicolumn{2}{|c|}{ Sample (2) } & \multicolumn{2}{|c|}{ Sample (3) } \\
\hline & (A) & (B) & (A) & (B) & (A) & (B) \\
\hline $\mathrm{Na}$ & 150 & 110 & 73 & 27 & 50 & 9 \\
\hline $\mathrm{Mg}$ & 14 & 10 & 20 & 13 & 9 & 2 \\
\hline $\mathrm{Al}$ & 130 & 80 & 240 & 130 & 76 & 70 \\
\hline $\mathrm{Cr}$ & 8 & $<10$ & 8 & 10 & 6 & $<10$ \\
\hline Mn & 3 & $<2$ & 3.9 & $<2$ & 2.9 & $<2$ \\
\hline $\mathrm{Fe}$ & 48 & 90 & 62 & 100 & 36 & 50 \\
\hline $\mathrm{Ni}$ & 9 & $<10$ & 8 & $<10$ & 7 & $<10$ \\
\hline $\mathrm{Cu}$ & 27 & 10 & 19 & 10 & 31 & 30 \\
\hline $\mathrm{Zn}$ & 19 & 20 & 19 & 20 & 11 & $<20$ \\
\hline $\mathrm{Pb}$ & 3 & $<4$ & 2.9 & $<4$ & 2.6 & $<4$ \\
\hline
\end{tabular}

(A) this method, (B) FAAS, wafers diameter $130 \mathrm{~mm}$.

concentration tendencies were in good agreement with the results of Sako et al. ${ }^{5)}$

Acknowledgement We wish to thank Prof. Yasumasa Shigetomi of Okayama University of Science for his helpful advice in this work.

\section{References}

1) Chung, H. Y., Kim, Y. H., Cho, H. Y., Lee, B. Y., Yoo, H. D. and Lee, S. H., Anal. Sci., Vol. 17, pp. 653-658 (2001).

2) Yamada, Y., Tachibe, T., Shimazaki, A., Takenaka, M. and Kozuka, S., Bunseki Kagaku, Vol. 50, pp. 453-458 (2001).

3) Fujiwara, K., Toumori, Y., Mitsumata, H., Inada, M. and Nakahara, T., Bunseki Kagaku, Vol. 48, pp. 681-685 (1999).

4) Nagasawa, H. and Enomoto, M., Bunseki Kagaku, Vol. 46, pp. 375-379 (1997).

5) Sako, N., Tanaka, H., Toyoda, M., Naka, J. and Kuramoto, K., Bunseki Kagaku, Vol. 43, pp. 771-776 (1994).

6) Nagasawa, H., Kato, Y. and Enomoto, M., Bunseki Kagaku, Vol. 44, pp. 953-956 (1995).

7) Yamagami, M., Nonoguchi, M., Yamada, T., Shoji, T., Utaka, T., Mori, Y., Nomura, S., Taniguchi, K., Wakita, H. and Ikeda, S., Bunseki Kagaku, Vol. 48, pp. 1005-1011 (1999).

8) Hunabashi, M., Utaka, T. and Arai, T., Spectrochim. Acta, Part B, Vol. 52, pp. 887-899 (1997).

9) Pahlke, S., Fabry, L., Kotz, L., Mantler, C. and Ehmann, T., Spectrochim. Acta, Part B, Vol. 56, pp. 2261-2274 (2001).

10) Ruth, K., Schmidt, P. and Mori, E. J., Spectroscopy, Vol. 7, pp. 36-36 (1992).

11) Takenaka, M., Tomita, M., Kubota, A., Tsuchiya, N. and Matsunaga, H., Bunseki Kagaku, Vol. 43, pp. 173-176 (1994).

12) Hub, W. and Amphlett, H., Analytical and Bioanalytical Chemistry, Vol. 350, pp. 587-592 (1994).

13) Shimazaki, A., Hiratsuka, H., Matsushita, Y. and Yoshii, S., Extended Abstracts of the 16th Coference on Solid State Devices Materials (1984) pp. 281-281.

14) Kojima, H., Hitachi Scientific Instrument News, Vol. 33, pp. 3129- 3129 (1990).

15) Kantor, T. and Margaretha T. C., Spectrochim. Acta, Part B, Vol. 60, pp. 333-343 (2005).

16) Gregoire, D. C., Al-Maawali, S. and Chakrabarti, C. L., Spectrochim. Acta, Part B, Vol. 47, pp. 1123-1132 (1992).

17) Ediger, R. D. and Beres, S. A., Spectrochim. Acta, Part B, Vol. 47, pp. 907-922 (1992).

18) Gregoire, D. C. and Sturgeon, R. E., Spectrochim. Acta, Part $B$, Vol. 54, pp. 773-786 (1999).

19) Mochizuki, T., "Purazuma Iongen Sitsuryou Bunseki," Ed. by Kawaguchi, K. and Nakahara, T., Gakkai Shuppan (1994) pp. 100-102 [in Japanese].

20) Tsukahara, R. and Kubota, M., Spectrochim. Acta, Part B, Vol. 45, pp. 779-787 (1990). 